\title{
A Decision Support Concept for a construction design project - selecting the type of glass façade
}

\author{
Katarina Rogulj ${ }^{1, \dagger}$, Nikša Jajac ${ }^{1}$ and Franjo Šimić ${ }^{1}$ \\ ${ }^{1}$ Faculty of Civil Engineering, Architecture and Geodesy, University of Split, Matice \\ hrvatske 15, 21000 Split, Croatia \\ E-mail: 〈\{kr0051,njajac,franjo.simic\}@gradst.hr $\rangle$
}

\begin{abstract}
The paper describes research into the possibility of developing a concept for supporting decisions in planning construction projects (one of the most important stages of construction project management). The focus is on supporting decisions in selecting the type of and solution for the glass façade in the main design. Materials and types of soluteons for a glass façade were analyzed and alternative solutions were obtained. The concept was developed in that it included relevant stakeholders in the decision-making process during the construction design. These stakeholders were the investor, architect, and construction contractor. The analysis was carried out and a hierarchical structure of objectives was formed as a goal tree. The criteria at the last hierarchical level were used to evaluate alternative solutions for the glass façade, and their weights were determined by all stakeholders using the AHP method (Analytic Hierarchy Process). Using PROMETHEE (Preference Ranking Method for Enrichment Evaluation), a comparison of alternative solutions for the glass façade was conducted and the alternatives were ranked according to the priorities for inclusion into the main design. The concept was tested by selecting a type of glass façade on a residential-commercial building in the city of Rijeka, Croatia.
\end{abstract}

Keywords: MCDM, project management, glass façade, AHP, PROMETHEE

Received: September 25, 2016; accepted: March 31, 2017; available online: March 31, 2017

DOI: $10.17535 /$ crorr. 2017.0021

\section{Introduction}

Deciding on how to maintain and manage a construction design project, especially when it comes to selecting the type of façade, can be a difficult and complex activity. The façade is the first thing a person notices on a building. Often that first impression creates and strongly influences the overall image of the building. The façade is an extremely important design and optical element. Selecting the right type of façade is important in order to achieve specific energy efficiency and

${ }^{\dagger}$ Corresponding author 
thermal comfort. The selection and design of the façade can be a guide in conceptualizing the entire facility. Therefore, the architect's main task is to design an interesting building façade, where the choice of materials used as façade cladding can be varied. The focus of this paper are glass façades. The period of observation is the life cycle of a building. One of the reasons for this is the economic factor. The initial cost of an investment may be lower, but the maintenance cost of the façade and its energy efficiency may subsequently be exceptionally high. The opposite is also true, i.e. the final price may be lower if the initial investment is higher, given that the maintenance and energy efficiency costs do not drastically increase future expenditures. The approach used to model the process of selecting the glass façade solution is multicriteria analysis. This same approach is used for many reasons, such as the number of possible solutions, the size and diversity of the analyzed problem (investment, economic, and ecological aspects) which should be considered, the need to engage various experts to deal with each of these issues (extensive knowledge that usually surpasses a single person's knowledge) and a high level of conflict in satisfying every aspect of the problem but where only one solution is possible. The decision-making process analyzes all aspects, introduces the relevant stakeholders, and includes the investor in investment decisions. Getting the investor involved in early gives that same investor confidence in the output of the concept. The concept outcome is the basis for making a final decision [10].

In the construction management stage, the wishes and needs of the investor, architect and construction contractor should be respected. The architect provides data on possible technical solutions, and the construction contractor is then able to clearly identify which solutions can be implemented within the defined deadlines and budget. Construction management focuses on the contracting process, selecting the construction contractor, planning execution, and monitoring construction. This approach improves the project management phase of designing building facade, but which is largely ignored in the building construction phase. This approach helps investors to sell real estate, architects to easily define project tasks and construction contractors to carry out construction. The end-users' opinion is considered under the investors' opinion, and is based on analyses of real estate markets while focusing on the requirements and needs of customers.

The specific concept based on multicriteria decision-making methods is presented in the paper. The concept provides support to the investor of the construction project in selecting the glass façade type.

Similar examples of devising concepts and decision support systems in planning construction projects for various building façades that provide a higher energy efficiency, thermal comfort, insulation, and better aesthetics to a building, can be found in the number of studies. These include Šiožinytė and Antuchevičienè [19] who present possible ways of improving indoor daylighting for vernacular architecture while endeavoring to retain tradition and satisfy minimal day lighting 
norms as stipulated by building regulations. This specific problem is evaluated using multicriteria methods. Hopfe et al. [6] discuss how decision-making can be based on uncertainty assessments. In this approach, key performance indicators such as energy efficiency, thermal comfort and others are ranked according to importance and preferences. Attia et al. [1] describe the implementation of a simulation-based decision support tool in the conceptual design of zero-energy buildings in order to assess thermal comfort and energy performance options. Friedrich and Luible $[5]$ in their study tried to identify the product attributes for a façade design that are of most interest to decision-makers. Zavadskas et al. [22] present a methodology enabling that allows the decision-maker to reach a decision by designing alternatives of a building's external walls and to evaluate attributes both qualitatively and quantitatively contained in the process. Hosseini et al. [7] investigate different types of exterior walls for the renewal and reconstruction of buildings in an earthquake area. This was achieved by using a group decisionmaking method. Stamatakis et al. [18] performed a multicriteria analysis of monocrystalline photovoltaic (PV) panels mounted on typical south-facing shading devices of office buildings in the Mediterranean region. Zagorskas et al. [21] researched the retrofitting the historical buildings, when only internal insulation is permitted due to the value of the façade or other heritage preservation constraints. The multicriteria method is used to select the best insulation option.

This research aims to design a Decision Support Concept (DSC) useful for investors in identifying an appropriate glass facade type (fulfilling esthetical, environmental or energy efficiency, and economic requirements) for a building during its design phase. The concept is tested on the residential-commercial building located in Rijeka, Croatia.

\section{Determining the design concept for a construction project - selecting the type of glass façade}

The Decision Support Concept (DSC) for the construction design - selecting the type of glass façade is based on the results of previous studies undertaken by $[11,13,14]$ and conducted in the field of the decision support concept for managing technical/construction projects.

The DSC (see Figure 1) has a basic structure: data, dialog, and model. Interactions between modules occur in decision-making processes at all management levels, and serve as meeting points of adequate models and data. The first level and lowest level supports the decision-maker at the operational decision level. The key functions at this level are to support the decision-maker, process data and information, and provide information flows for higher decision levels. The second level provides tactical decisions and creates an information basis and solutions or models for the strategic decision level. Decisions are made by individual experts 
and expert teams, as well as the representatives of local political bodies and public companies with social responsibilities. At the third level, a future development of the system is carried out based on the expert deliverables from the second (tactical) level. These strategies are for lower decision and management levels, thus ensuring continuity of decision-making processes throughout decision and management systems. Both strategic and tactical levels use more complex techniques and knowledge than the operational level [14]. In this paper, the logic behind the cited decision support system is used to design a new decision support concept specifically for the design phase in selecting the type of glass façade in a construction project.

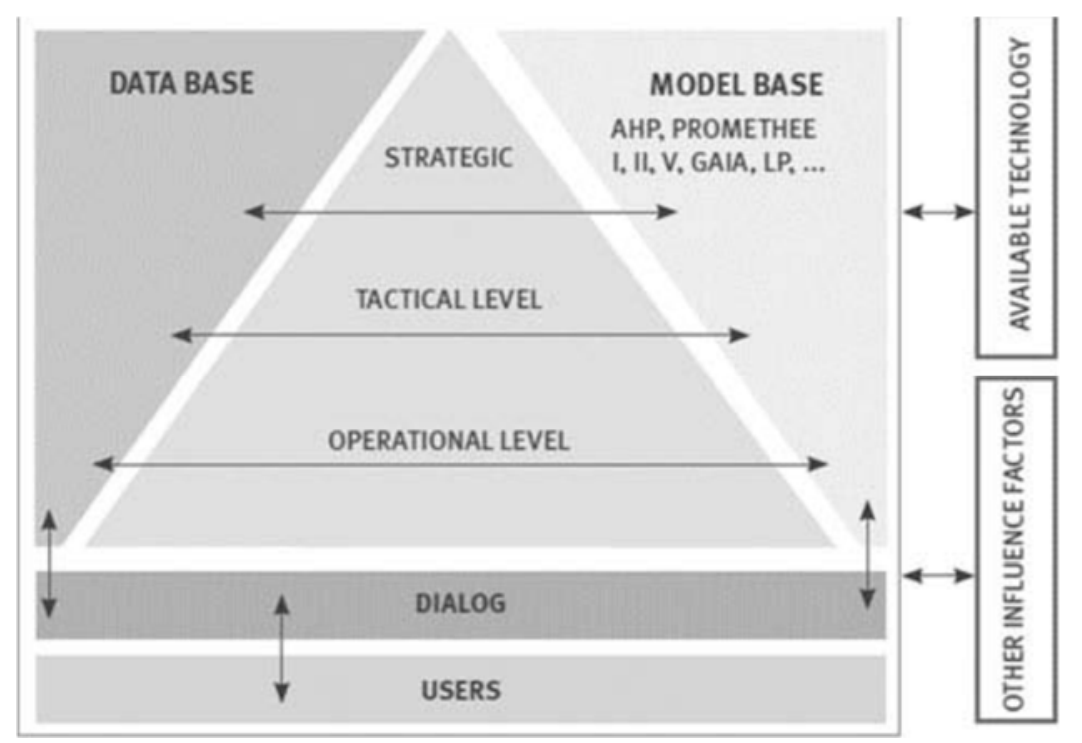

Figure 1: Architecture of the Decision Support Concept for urban infrastructure engagement $[11,13,14]$

This paper proposes the use of the Decision Support Concept for a specific part of the construction design - the type of glass façade. The concept presents the methodology to be used by decision-makers when planning the construction project management. Following the principles and logic of the DSC, and according to the sequence and patterns of decision-making processes identified as important within the design phase of a construction project in selecting the type of glass façade, a novel DSC was generated. Figure 2 presents the DSC for construction project design in selecting the type of glass façade based on a multicriteria approach to problem solving. 


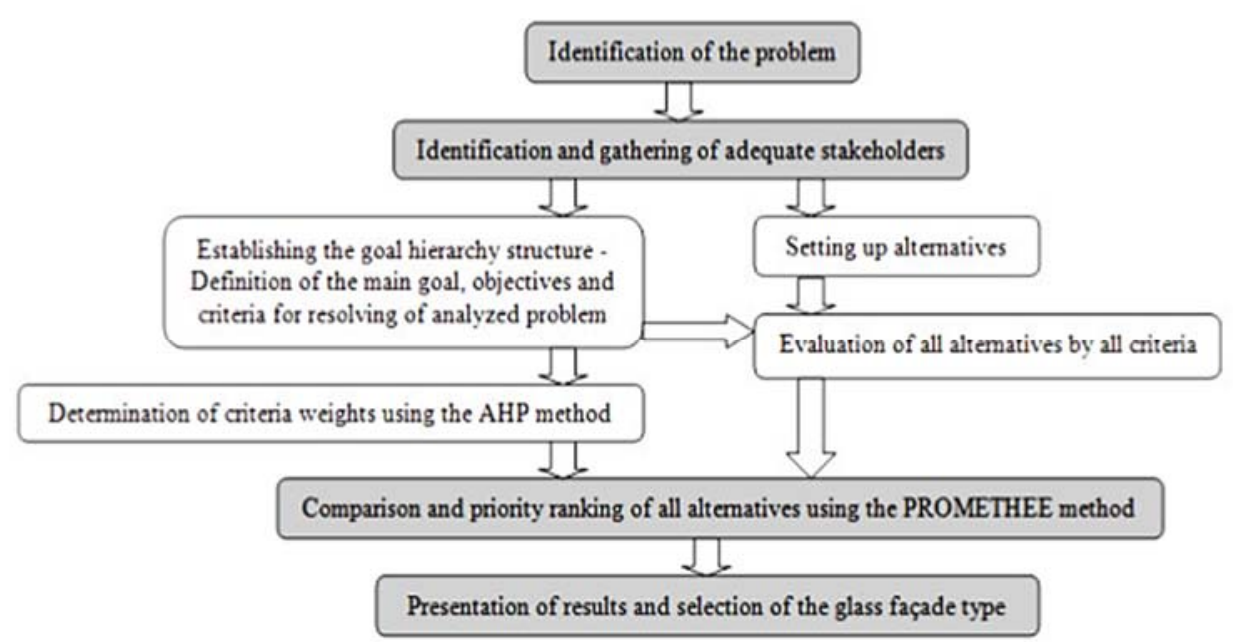

Figure 2: The Decision Support Concept for the construction project design - selecting the type of glass façade

The first two steps of the proposed concept are identifying an ill-structured problem and defining relevant stakeholders. The identification of stakeholders in the management process is not a simple task. In designing the proposed DSC, three stakeholders were identified that should be invited to participate in its application: the investor (and/or its representative - project manager), architect (author of the conceptual design and/or its representative) and construction contractor (representative of the company carrying out the construction works and possessing extensive experience in similar projects). These stakeholders should be involved in designing the goal hierarchy structure in the form of a goal tree. The goal tree should be devised in group decision-making after brainstorming on the research problem. Establishing the goal tree starts with a definition of the main goal. The following step in establishing the goal tree is defining its objectives (dividing the main goal into several supporting objectives or first level objectives). Subsequently, sub-objectives of the first-level objectives must be provided. The process of generating sub-objectives must be repeated until the generated objectives do not need to be or cannot be divided anymore [8]. In fact, when it is impossible to generate sub-objectives of an objective and that objective is measurable, the objective becomes a criterion [12]. Criteria established in this manner will be used to evaluate possible solutions or alternatives for the type of glass façade. When the process of dividing objectives into sub-objectives is finished, the goal tree is established. While establishing the goal tree, it is important to identify possible alternatives, which should be different combinations of structures and materials of a future façade and comply with the conceptual design of the building. Using the AHP (Analytic Hierarchy Processing) method 
[16] and in line with both the established goal tree and stakeholders' views, the importance of criteria (weights for each criterion) should be provided. Multicriteria decision-making is supported by several strategies also known as scenarios. In taking several preliminary scenarios (in this case three scenarios one for each stakeholder), the compromise scenario (final scenario) can be defined and used for a comparison/ranking of alternatives. The final scenario is defined as a set of compromise criteria weights, each of which is the average of the preliminary weights for the same criterion over all preliminary scenarios [9]. The next step in implementing the proposed DSC is evaluation of defined alternatives using all defined criteria.

A comparison of alternatives is obtained using the multicriteria method PROMETHEE [3]. The preference function must be established and the minimum and the maximum must be determined for each criterion. The result of this method (step) is a priority ranking list of alternatives. The ranking provides a quality foundation for making a decision on the type of glass façade. This foundation enables the investor to select an appropriate glass façade.

The previous considerations and Figure 2 therefore explain the general model for supporting processes related to the design of the construction project which in this case (as described above) is applied to the selection of the glass façade type. In addition, Figure 2 illustrates how stakeholders participate in the process of selecting the type of glass façade. Only the investor or his representative - project manager are to participate in the gray colored rectangles, whereas all stakeholders may participate in other rectangles. Their participation leads to better design transparency selecting glass façades in construction projects and also encourages stakeholders in achieving the project.

\section{Methodology and results}

Two of the different types of multi-criteria decision-making methods used in this paper are the AHP and the PROMETHEE. Each criterion weight is determined using the AHP method. This is followed by assessing each alternative (type of glass facade) based on all available criteria. Finally, the complete ranking of alternatives is conducted using the PROMETHEE method.

\subsection{The AHP method}

The AHP is a multi-criteria decision-making method which has attracted the interest of many researchers due to its convenient mathematical properties [20]. The method ranks alternatives according to certain criteria. Solving complex decisionmaking problems using the AHP relies on breaking down problems into their components: objective, criteria (sub-criteria), and the alternatives [2]. Making an 
organized decision to generate priorities requires decomposing the decision needs into the following steps [17]:

- Define the problem;

- Structure the decision hierarchy;

- Construct a set of pair wise comparison matrices;

- For each element, use the priorities obtained from the comparison to weigh the priorities at the level immediately below. Then each element at the level below receives its weighed value. This weighing process is continued until the final priorities of the alternatives at the bottom level are obtained.

Doing comparisons requires a scale of numbers. The scale indicates how many times one element is more dominant or important than another element with respect to the criterion or property with respect to which they are compared [17]. In this paper, Saaty's evaluation scale was applied [16].

It is relatively easy to assign the weights of criteria in a group decision-making process using the multicriteria AHP method by interviewing experts, as well as other stakeholders such as civil representatives or NGOs, etc. [8]. The ranking of criteria for evaluating alternatives using the AHP method will give their weights, i.e. the results of the ranking will be used to define weights of the criteria [14].

The AHP method has proven to be useful for removing stakeholder subjectivity in the process of criteria weights determination, and more important for determining (and controlling) the level of consistency when estimating the importance (weight) of criteria during the process of determination of their weights with mutual comparison.

\subsection{The PROMETHEE method}

The PROMETHEE method is well-accepted among decision-makers as it is comprehensive and presents results using a simple ranking. It compares and ranks various alternatives that are at the same time valued on the basis of several qualitative or quantitative criteria.

A matrix consisting of a set of potential alternatives $\mathrm{A}$ is an input for the PROMETHEE method. Each $a$ element of $A$ is $f(a)$ which represents evaluation of one criterion and each evaluation $f_{i}\left(a_{i}\right)$ must be a real number. The PROMETHEE I method gives the partial relation and then from the PROMETHEE II method, which ranks the actions by the complete ranking calculating net flow, a net outranking flow is obtained [3]:

$$
\Phi(\mathrm{a})=\Phi^{+}(\mathrm{a})-\Phi^{-}(\mathrm{a})
$$

$\Phi^{+}$(a) is the positive outranking flow and is defined as: 


$$
\Phi^{+}(\mathrm{a})=\frac{1}{n-1} \sum_{x \in A} \Pi(a, x)
$$

and $\Phi^{-}(\mathrm{a})$ is the negative outranking flow defined as:

$$
\Phi^{-}(\mathrm{a})=\frac{1}{n-1} \sum_{x \in A} \Pi(x, a)
$$

where $a$ and $x$ are the actions from the set of actions $A$ (during the pairwise comparison of action $a$ with all other $n$ - 1 actions), $n$ represents the number of actions and $\Pi$ is the preference index defined for each pair of actions:

$$
\prod(a, b)=\frac{\sum_{j=1}^{m} w_{j} P_{j}(a, b)}{\sum_{i=1}^{m} w_{j}}
$$

Where $P_{j}(a, b)$ represents preference of $a$ over $b$ for a given preference function of criterion $j$, and $w_{j}$ is a weight of criterion $j$. Since $\sum_{j=1}^{m} w_{j}=1$, equation (4) changes its expression into: $\prod(a, b)=\sum_{j=1}^{m} w_{j} P_{j}(a, b)$.

There are six types of preference functions proposed by the authors of the method [3,4]: Usual criterion, U-shape criterion, V-shape criterion, Level criterion, Linear criterion, and Gaussian criterion. The analyst and the decision-maker, in mutual agreement, choose one of the six functions for each criterion with regard to their knowledge of the intensity and direction of a preference. In each particular case, some parameters are to be determined in advance. Each of the parameters has a real economic meaning and they are: parameter $q$ is the indifference threshold, parameter $p$ is preference threshold, and parameter $\sigma$ represents the Gaussian threshold.

Different sets of criteria weights can be used and then each set represents one scenario. Experts and sometimes other stakeholders usually determine criteria weights.

\subsection{Validation of the Decision Support Concept}

The proper selection of the type of glass façade requires developing a specific decision-making process and additionally specific support. For this reason, the previously presented concept was designed, and the validation of which is displayed below. The decision-making process starts by identifying and gathering an adequate set of stakeholders. Three stakeholders were involved in making the decision: investor, architect, and construction contractor. "The selection of the appropriate type of glass façade" was defined as the main goal. Having defined the main goal, the stakeholders continued with designing the goal hierarchy structure by generating objectives and criteria that support the main goal. Achieving objectivity of the design process was the crucial issue, especially when defining the most relevant objectives and criteria. Therefore, all stakeholders 
reached consensus on each hierarchy element (objective or criterion) before it was included in the goal hierarchy structure. The designed goal hierarchy structure is shown in Figure 3 along with a detailed description below the same figure. The three objectives of the main goal are: (1) economic benefits, (2) technological functionality, and (3) ecological benefits. These objectives are the result of stakeholder consensus in addressing all the important aspects of the respective problem. Therefore, each of the three mentioned objectives represent an aspect or issue of the analyzed problem important to stakeholders and which were successfully addressed and considered.

This principle is used to define objectives (criteria) from next (lower) level and to ensure sufficient objectivity in designing a goal hierarchical structure. The mentioned principle proved to be useful as it does not require the stakeholders to adapt too much to the new methodology, the principle is understandable and similar to decision-making practices of all stakeholders. In this manner, a set of criteria used for evaluating alternative solutions for the façade was defined. These criteria directly support the achieving of upper level objectives, the criteria are measurable and do not have to be further divided (indirectly through objectives, criteria facilitate achieving the main goal). In Figure 3, the criteria are marked as $\mathrm{Cn}$, where $\mathrm{n}=1 \ldots 9$ is the criterion number.

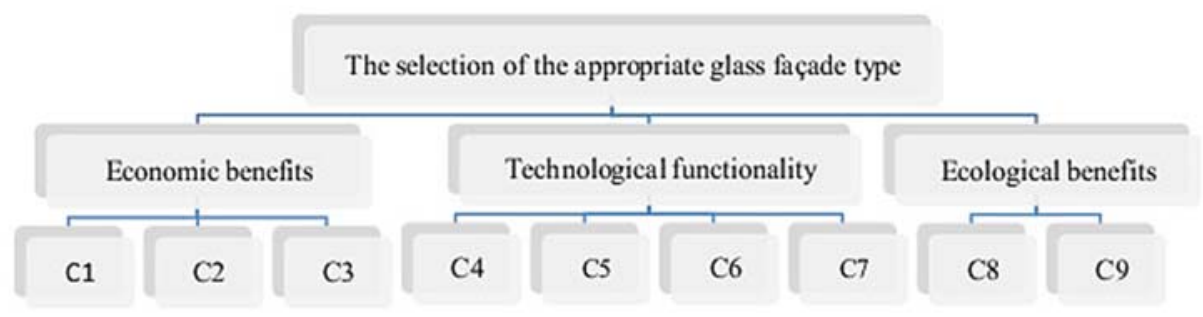

Figure 3: The goal hierarchy structure for the problem of selecting the type of glass façade in the construction design

In Table 1, the criterion characteristics are label, full name, short description, assessment technique, and the preference method for each criterion. The analysis indicated that five criteria were to be minimized, i.e. a lower assessed value was preferred for the criteria. In addition, the remaining four criteria were to be maximized, meaning higher assessed values were preferred for the criteria. Each criterion has its own preference function, and these functions represent the method the decision-maker forms a preference between two alternatives based on the respective criterion. The value of the preference function is between 0 and 1 . The smaller the value of the function, the bigger the indifference of the decision-maker. If the value is closer to 1 , the preference of the decision-maker is higher. In the case of a strict preference, the value of the function will be 1 . The number of types 
of preference functions depends on the characteristics of the determined and used criteria. In this case, the V-Shape function of preferences is used for all criteria, based on stakeholder experience, to describe the decision-making method in solve this problem. The authors chose to use only one preference function type and explained their decision by stating that a single preference is a characteristic type of preference function in civil engineering although they were aware that the selection of preference function usually depends on chosen criteria. They found that the $\mathrm{V}$-Shape is a function which is easy to understand and is a suitable preference function type for all criteria. It must be emphasized that 6 preference functions, which are usually used when PROMETHEE is employed, were presented to all stakeholders. Furthermore, the authors referred to several papers from Croatia (the same area where presented concept is validated) also using PROMETHEE to support decision-making in the field of civil engineering which also strongly support the previous statement $[10,13,14]$. In addition, the authors have encountered similar situations in practice (as experts in planning civil engineering investments in Croatia and Bosnia \& Herzegovina) and the results regarding the selection of preference function were almost the same. A decisionmaker's selection of the preference function must be respected because when using an MCDM method such as PROMETHEE, the obtained results must be accepted as subjective results given that they represent compromised solutions and represent the opinions (views) of stakeholders on the analyzed problem.

\begin{tabular}{|l|c|l|l|c|}
\hline $\begin{array}{c}\text { Criteria } \\
\text { label }\end{array}$ & $\begin{array}{c}\text { Criteria } \\
\text { name }\end{array}$ & $\begin{array}{c}\text { Short description of criteria and its } \\
\text { assessment technique }\end{array}$ & $\begin{array}{c}\text { Preference } \\
\text { function }\end{array}$ & $\begin{array}{c}\text { Min/ } \\
\text { Max }\end{array}$ \\
\hline C1 & $\begin{array}{c}\text { Constru- } \\
\text { ction cost }\end{array}$ & $\begin{array}{l}\text { Overall construction costs. } \\
\text { Expressed in EUR/m }{ }^{2}\end{array}$ & V-shape & Min \\
\hline Façade \\
$\begin{array}{c}\text { maintena- } \\
\text { nce cost }\end{array}$ & $\begin{array}{l}\text { Overall façade maintenance costs } \\
\text { per year over a period of } 20 \text { years } \\
\text { calculated from the moment of } \\
\text { completion of the building. } \\
\text { Expressed in EUR/20 years }\end{array}$ & V-shape & Min \\
\hline C3 & $\begin{array}{c}\text { Energy } \\
\text { budget }\end{array}$ & $\begin{array}{l}\text { Overall energy budget per one } \\
\text { year. Expressed in EUR/1 year }\end{array}$ & V-shape & Min \\
\hline $\begin{array}{c}\text { Comple- } \\
\text { xity of the } \\
\text { constru- } \\
\text { ction }\end{array}$ & $\begin{array}{l}\text { Expert's assessment of the } \\
\text { complexity of the construction } \\
\text { design, grading: } 1 \text {-simple } \\
\text { construction, 2-medium complex } \\
\text { construction, 3- complex } \\
\text { construction }\end{array}$ & V-shape & Min \\
\hline C5 & $\begin{array}{c}\text { Façade } \\
\text { esthetics }\end{array}$ & $\begin{array}{l}\text { Expert's assessment, grading: } \\
\text { 1(worst)-10(best) }\end{array}$ & V-shape & Max \\
\hline
\end{tabular}




\begin{tabular}{|l|c|l|l|l|}
\hline C6 & $\begin{array}{c}\text { Function- } \\
\text { ality of } \\
\text { use }\end{array}$ & $\begin{array}{l}\text { Expert's assessment, grading: } \\
1 \text { (worst)-10(best) }\end{array}$ & V-shape & Max \\
\hline C7 & Safety & $\begin{array}{l}\text { Expert's assessment of the glass } \\
\text { safety level in terms of its } \\
\text { dissipation in the case of breaking, } \\
\text { grading: 1-toughened glass, 2- } \\
\text { laminated glass, 5-toughened } \\
\text { laminated glass with correction } \\
\text { performed by multiplying by 1,5 in } \\
\text { the case of triple glazing, reducing } \\
\text { the possibility of spreading of the } \\
\text { glass during breakage }\end{array}$ & V-shape & Max \\
\hline C8 & $\begin{array}{l}\text { Heat } \\
\text { transfer } \\
\text { coefficient }\end{array}$ & $\begin{array}{l}\text { Expressed with the size of thermal } \\
\text { transmittance for double and triple } \\
\text { glazing }\left(\mathrm{W} / \mathrm{m}^{2} \mathrm{~K}\right)\end{array}$ & V-shape & Min \\
\hline C9 & $\begin{array}{c}\text { Energy } \\
\text { savings }\end{array}$ & Expressed in $(\mathrm{kWh} /$ year) & V-shape & Max \\
\hline
\end{tabular}

Table 1: Criteria and preference function

Each stakeholder estimated the criterion weights separately. The criterion weights were defined using stakeholder preferences, whereas the AHP was used to determine the importance of the criteria in achieving the higher level objectives. In this case, three scenarios were created for the problem as follows: investor (scenario 1), architect (scenario 2), and construction contractor (scenario 3). Regarding the AHP rules for comparing goals and criteria, all stakeholders compared each criterion with other criteria to determine the criterion's relative importance in achieving the direct parent goal, and also the relative importance for achieving (indirectly) the main goal [13]. this begins from the main goal and leads to the last level of hierarchy (criteria). The sum of all criterion weights is $100 \%$. Table 2 presents three scenarios (of criterion weights), including the average criterion weights. The obtained average values of weights represent the compromise weights, as all stakeholders were equally involved in determining the weights.

When applying the AHP method, the consistency ratio (CR) is to be take into account. If the $\mathrm{CR}$ value is less than or equal to 0.1 , the weights are calculated properly $\left(\mathrm{CR}_{\text {investor }}=0.08 ; \mathrm{CR}_{\text {architect }}=0.07 ; \mathrm{CR}_{\text {construction contractor }}=0.09\right)$, meaning the inconsistency is less than $10 \%$. 


\begin{tabular}{|l|c|c|c|c|c|}
\hline \multirow{2}{*}{$\begin{array}{c}\text { Criteria } \\
\text { label }\end{array}$} & Criteria name & \multicolumn{4}{|c|}{ Weight } \\
\cline { 3 - 6 } & & $\begin{array}{c}\text { Scenario } \\
1\end{array}$ & $\begin{array}{c}\text { Scenario } \\
2\end{array}$ & $\begin{array}{c}\text { Scenario } \\
3\end{array}$ & Average \\
\hline C1 & The construction cost & 0.30 & 0.12 & 0.12 & 0.18 \\
\hline C2 & $\begin{array}{c}\text { The façade maintenance } \\
\text { cost }\end{array}$ & 0.14 & 0.08 & 0.08 & 0.10 \\
\hline C3 & The energy budget & 0.10 & 0.07 & 0.04 & 0.07 \\
\hline C4 & $\begin{array}{c}\text { The complexity of the } \\
\text { construction }\end{array}$ & 0.03 & 0.08 & 0.40 & 0.17 \\
\hline C5 & The façade aesthetics & 0.15 & 0.35 & 0.13 & 0.21 \\
\hline C6 & Functionality of using & 0.05 & 0.10 & 0.08 & 0.077 \\
\hline C7 & Safety & 0.09 & 0.05 & 0.05 & 0.063 \\
\hline C8 & Heat transfer coefficient & 0.06 & 0.07 & 0.05 & 0.06 \\
\hline C9 & Energy savings & 0.08 & 0.08 & 0.05 & 0.07 \\
\hline
\end{tabular}

Table 2: Criteria weights for 3 scenarios

The weight distributions for the three scenarios, shown in Table 2, are as expected. Specifically, the investor considers C1 to C3 as the most important criteria, where $\mathrm{C} 1$ has the largest and $\mathrm{C} 3$ the lowest weight value. The architect considers $\mathrm{C} 4$ to $\mathrm{C} 7$ to be the most important criteria, whereas the construction contractor points out that $\mathrm{C} 8$ and $\mathrm{C} 9$ are equally important criteria. The compromise scenario is a uniformly expressed consideration of all stakeholders (investor, architect, and construction contractor) in selecting the appropriate façade. This scenario applies the PROMETHEE method in the comparing process below.

Three fundamental solutions of the glass façade are presented: continuum façade, structural façade, and semi-structural façade. Based on these three solutions, alternatives are provided that consider the type of glass (glazing), type of insulation fill and the number of glasses. Table 3 presents alternatives (with label and name/description) as a combination of the three main types of glass facçades, type of glass (toughened glass, laminated glass, and toughened laminated glass), type of insulation fill, and number of glasses (thermal profile and triple glass, cold profile and double glass). There are 18 alternative solutions for the glass façade. 


\begin{tabular}{|c|c|}
\hline $\begin{array}{c}\text { Alternative } \\
\text { label }\end{array}$ & Name/description of alternative \\
\hline $\mathrm{CF} 1$ & $\begin{array}{c}\text { Continuum façade }+ \text { toughened glass }+ \text { thermal profile and } \\
\text { triple glass }\end{array}$ \\
\hline $\mathrm{CF} 2$ & $\begin{array}{c}\text { Continuum façade }+ \text { toughened glass }+ \text { cold profile and } \\
\text { double glass }\end{array}$ \\
\hline CF3 & $\begin{array}{c}\text { Continuum façade }+ \text { laminated glass }+ \text { thermal profile and } \\
\text { triple glass }\end{array}$ \\
\hline CF4 & $\begin{array}{c}\text { Continuum façade }+\begin{array}{l}\text { laminated glass }+ \text { cold profile and } \\
\text { double glass }\end{array} \\
\end{array}$ \\
\hline CF5 & $\begin{array}{c}\text { Continuum façade }+ \text { toughened laminated glass }+ \text { thermal } \\
\text { profile and triple glass }\end{array}$ \\
\hline CF6 & $\begin{array}{c}\text { Continuum façade }+ \text { toughened laminated glass }+ \text { cold } \\
\text { profile and double glass }\end{array}$ \\
\hline SF1 & $\begin{array}{c}\text { Structural façade }+ \text { toughened glass }+ \text { thermal profile and } \\
\text { triple glass }\end{array}$ \\
\hline SF2 & $\begin{array}{c}\text { Structural façade }+ \text { toughened glass }+ \text { cold profile and } \\
\text { double glass }\end{array}$ \\
\hline SF3 & $\begin{array}{c}\text { Structural façade }+\begin{array}{l}\text { laminated glass }+ \text { thermal profile and } \\
\text { triple glass }\end{array} \\
\end{array}$ \\
\hline SF4 & $\begin{array}{c}\text { Structural façade }+ \text { laminated glass }+ \text { cold profile and } \\
\text { double glass }\end{array}$ \\
\hline SF5 & $\begin{array}{c}\text { Structural façade }+ \text { toughened laminated glass }+ \text { thermal } \\
\text { profile and triple glass }\end{array}$ \\
\hline SF6 & $\begin{array}{c}\text { Structural façade }+ \text { toughened laminated glass }+ \text { cold profile } \\
\text { and double glass }\end{array}$ \\
\hline SSF1 & $\begin{array}{c}\text { Semi-structural façade }+ \text { toughened glass }+ \text { thermal profile } \\
\text { and triple glass }\end{array}$ \\
\hline SSF2 & $\begin{array}{c}\text { Semi-structural façade }+ \text { toughened glass }+ \text { cold profile and } \\
\text { double glass }\end{array}$ \\
\hline SSF3 & $\begin{array}{c}\text { Semi-structural façade }+ \text { laminated glass }+ \text { thermal profile } \\
\text { and triple glass }\end{array}$ \\
\hline SSF4 & $\begin{array}{c}\text { Semi-structural façade }+ \text { laminated glass }+ \text { cold profile and } \\
\text { double glass }\end{array}$ \\
\hline SSF5 & $\begin{array}{c}\text { Semi-structural façade }+ \text { toughened laminated glass }+ \\
\text { thermal profile and triple glass }\end{array}$ \\
\hline SSF6 & $\begin{array}{c}\text { Semi-structural façade }+ \text { toughened laminated glass }+ \text { cold } \\
\text { profile and double glass }\end{array}$ \\
\hline
\end{tabular}

Table 3: Alternatives/solutions for the glass façade 


\begin{tabular}{|l|c|c|c|c|c|c|c|c|c|}
\hline $\begin{array}{c}\text { Alterna- } \\
\text { tives/ } \\
\text { Criteria }\end{array}$ & $\mathrm{C} 1$ & $\mathrm{C} 2$ & $\mathrm{C} 3$ & $\mathrm{C} 4$ & $\mathrm{C} 5$ & $\mathrm{C} 6$ & $\mathrm{C} 7$ & $\mathrm{C} 8$ & $\mathrm{C} 9$ \\
\hline CF1 & 196000 & 56000 & 43041.453 & 1 & 1 & 1 & 1.5 & 0.89 & 5922 \\
\hline CF2 & 189000 & 56000 & 43775.571 & 1 & 1 & 1 & 1 & 1.4 & 928 \\
\hline CF3 & 231000 & 56000 & 43041.453 & 1 & 1 & 1 & 1.5 & 0.89 & 5922 \\
\hline CF4 & 224000 & 56000 & 43775.571 & 1 & 1 & 1 & 1 & 1.4 & 928 \\
\hline CF5 & 266000 & 56000 & 43041.453 & 1 & 1 & 1 & 1.5 & 0.89 & 5922 \\
\hline CF6 & 259000 & 56000 & 43775.571 & 1 & 1 & 1 & 1 & 1.4 & 928 \\
\hline SF1 & 266000 & 84000 & 43201.83 & 3 & 10 & 10 & 4.5 & 0.9 & 4831 \\
\hline SF2 & 259000 & 84000 & 43911.987 & 3 & 10 & 10 & 3 & 1.5 & 0 \\
\hline SF3 & 301000 & 84000 & 43201.83 & 3 & 10 & 10 & 4.5 & 0.9 & 4831 \\
\hline SF4 & 294000 & 84000 & 43911.987 & 3 & 10 & 10 & 3 & 1.5 & 0 \\
\hline SF5 & 336000 & 84000 & 43201.83 & 3 & 10 & 10 & 4.5 & 0.9 & 4831 \\
\hline SF6 & 329000 & 84000 & 43911.987 & 3 & 10 & 10 & 3 & 1.5 & 0 \\
\hline SSF1 & 217000 & 70000 & 43201.83 & 2 & 7 & 8 & 3 & 0.9 & 4831 \\
\hline SSF2 & 210000 & 70000 & 43911.987 & 2 & 7 & 8 & 2 & 1.5 & 0 \\
\hline SSF3 & 252000 & 70000 & 43201.83 & 2 & 7 & 8 & 3 & 0.9 & 4831 \\
\hline SSF4 & 245000 & 70000 & 43911.987 & 2 & 7 & 8 & 2 & 1.5 & 0 \\
\hline SSF5 & 287000 & 70000 & 43201.83 & 2 & 7 & 8 & 3 & 0.9 & 4831 \\
\hline SSF6 & 280000 & 70000 & 43911.987 & 2 & 7 & 8 & 2 & 1.5 & 0 \\
\hline
\end{tabular}

Table 4: Decision matrix

In Table 4, the decision matrix is shown and assessments of alternatives across all observed criteria are presented in rows. With the aid of the software Visual PROMETHEE [15], multicriteria data were processed using the multicriteria method PROMETHEE II and compromise ranking was generated. The PROMETHEE II method provides a complete ranking by mutual comparison of all types of glass façades with every criterion according to stakeholders' opinions, which are expressed through given criteria weights and selected preferences functions. The complete ranking and net flow ( $\Phi$ ) for a compromise (average) scenario is shown in Table 5, and the graphical presentation of net flow results and complete ranking of the compromise (average) scenario is given in Figure 4. 


\begin{tabular}{|c|l|c|}
\hline Rank & $\begin{array}{c}\text { The glass façade } \\
\text { type } \\
\text { (alternative) }\end{array}$ & $\begin{array}{c}\text { Net flow } \\
(\Phi)\end{array}$ \\
\hline 1 & SSF1 & 0.1799 \\
\hline 2 & CF1 & 0.1438 \\
\hline 3 & SSF3 & 0.1345 \\
\hline 4 & CF3 & 0.0984 \\
\hline 5 & SF1 & 0.0943 \\
\hline 6 & SSF5 & 0.0891 \\
\hline 7 & CF5 & 0.0531 \\
\hline 8 & SF3 & 0.0489 \\
\hline 9 & SF5 & 0.0035 \\
\hline 10 & SSF2 & -0.0079 \\
\hline 11 & CF2 & -0.0348 \\
\hline 12 & SSF4 & -0.0533 \\
\hline 13 & CF4 & -0.0801 \\
\hline 14 & SSF6 & -0.0986 \\
\hline 15 & SF2 & -0.1031 \\
\hline 16 & CF6 & -0.1255 \\
\hline 17 & SF4 & -0.1484 \\
\hline 18 & SF6 & -0.1938 \\
\hline
\end{tabular}

Table 5: Net flow results and complete ranking for compromise (average) scenario

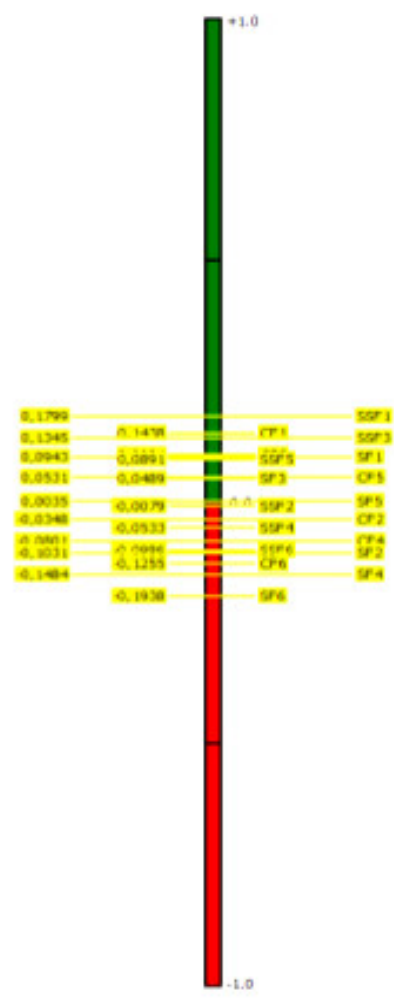

Figure 4: Graphical presentation of net flow results and PROMETHEE II complete ranking for compromise (average) scenario

It is evident from the results in Table 5 and Figure 4 that the alternative SSF 1 (semi-structural facade + toughened glass + thermal profile and triple glass) has the highest net flow $\Phi=0.1799$, and SF6 (structural façade + toughened laminated glass + cold profile and double glass) the lowest $\Phi=-0.1938$ net flow. Differences between alternatives of glass façade are quite small and there are no large deviations. The obtained results indicate that due minor differences between the sets of evaluated criteria, the criteria are to be further developed, in order to perhaps even reject some of the criteria used or replace some of the criteria with new criteria in order to get results which would enable the decision maker to choose the best ranked alternative with more certainty.

The relationship between alternatives for the glass façade of the building as well as their grouping, which is not clearly evident from the data in Table 5, but is clearly evident in the visual presentation. Table 5 can be used for a more detailed analysis of the relationship between certain alternatives by determining differe- 
nces in net flows. However, such a presentation makes it difficult to reach conclusions and finally make a choice.

An analysis of the results is now possible based on the previous paragraphs, along with Figure 4 and Table 5. This means that it provides a simple and concise basis for the final decision-maker to select the type of glass façade. Although SSF1 proved to be the most appropriate solution for the glass façade, the investor (i.e. decision-maker) is able to make a selection from among the first several solutions without making a serious mistake because of the small differences in net flow between them.

The concept is useful as it considers the analyzed problems associated with selecting a glass façade from all relevant aspects, and deals with a large amount of diverse data related to the problem involving all stakeholders in the selection process. It improves the quality of decision-making.

\section{Conclusion}

The goal of the paper is to find a solution for the type of glass façade in construction design phase. Three stakeholders were involved in undertaking the project: investor, architect, and building contractor. Selecting the type of glass façade is a poorly structured problem and a complex decision-making process, requiring optimally efficient problem-solving methods using appropriate decision tools. Therefore, scientific methods that include and assesse a large amount of information may provide the most rational solutions. This paper proposes the multicriteria decision-making method for complex decision-making problems in the construction design, especially when in selecting the glass façade. Using the multicriteria decision-making methodology can greatly assist in choosing the type of glass façade, which in this case involves a residential-commercial complex in Rijeka, Croatia. The multicriteria method using the AHP technique evaluated the weights for each criterion defined for the overall project objective. It enabled the decision-makers to visualize the impact of each criterion on the final result. The PROMETHEE II method gave a complete ranking of the alternatives (solutions to the glass façade) proposed by the stakeholders. Eighteen alternatives were presented and ranked by this method. The semi-structural façade + toughened glass + thermal profile and triple glass was ranked first in the compromise (average) scenario. In the paper, it can be concluded that the decision-support concept was established for the construction design - selecting the type glass façade. In future studies, the methodology of the decision support concept for the construction design should be adjusted for other buildings, in terms of possible façade solutions. If that is the case then different elements within the second level of hierarchy structure should be identified. Meaning, relevant criteria, and scenarios for assessment of solutions of such construction element should be defined. 


\section{References}

[1] Attia, S., Gratia, E., De Herde, A., Hensen, J. L.M. (2012). Simulation-based decision support tool for early stages of zero-energy building design. Energy and Buildings June. 49, 2-15.

[2] Babić. Z. (2011). Models and Methods of Business Decision Making. Faculty of Economics, Split, Croatia.

[3] Brans, J.P., Mareschal, B., Vincke, P.H. (1984). PROMETHEE - a new family of outranking methods in multicriteria analysis. Operational Research IFORS 84.J.P. Brans (Ed.), Amsterdam, North Holland, Netherlands, 477490.

[4] Brans, J.P., Vincke, P.H. (1985). A preference ranking organization method, the PROMETHEE method for MCDM. Management Science, 31, 647-656. Available at: http://dx.doi.org/10.1287/mnsc.31.6.647

[5] Friedrich, D., Luible, A. (2016).Assessment of standard compliance of Central European plastics-based wall cladding using multi-criteria decision-making (MCDM). Case Studies in Structural Engineering, 5, 27-37.

[6] Hopfe, C.J., Augenbroe, G.L.M, Hensen, J.L.M. (2013).Multi-criteria decision making under uncertainty in building performance assessment. Building and Environment, 69, 81-90.

[7] Hosseini, S.T., Arefi, S.L., Bitarafan, M., Abazarlou,S., Zavadskas, E.K. (2016). Evaluation types of exterior walls to reconstruct Iran earthquake areas (AharHerisVarzeqan) by using AHP and fuzzy methods. International Journal of Strategic Property Management, 20(3), 328-340.

[8] Jajac, N. (2007).Design of decision support systems in the management of infrastructure systems of the urban environment. M.Sc. thesis, University of Split, Faculty of Economics, Split, Croatia.

[9] Jajac, N. (2010). Modelling of decision support systems on the development and maintenance of urban road infrastructure. PhD thesis, University of Split, Faculty of Economics, Split, Croatia.

[10] Jajac, N., Bilić, I., Ajduk, A. (2012). Decision Support Concept to management of construction projects - problem of construction site selection. Croatian Operational Research Review, 4(1), 235-247.

[11] Jajac, N., Knezić, S., Marović, I. (2009). Decision support system to urban infrastructure maintenance management. Organization, technology and management in construction, 1(2), 72-79.

[12] Jajac, N., Marović, I., Baučić, M. (2014). Decision support concept for managing the maintenance of city parking facilities. e-GFOS, 9, 60-69.

[13] Jajac, N., Marović, I., Hanak, T. (2015). Decision Support to management of transportation projects: improvement of urban road infrastructure planning. Građevinar, 67(2), 131-141. 
[14] Jajac, N., Rogulj, K., Radnić, J. (2016). Selection of the method for mehabilitation of historic bridges - Decision Support Concept for planning of rehabilitation projects. International Journal of Architectural Heritage, 11(2), 261277.

[15] Mareschal, B. (2011).Visual PROMETHEE. Available at: http://www.prome thee-gaia.net/visualpromethee. html

[16] Saaty, T. L. (1980). The Analytic Hierarchy Process. McGraw-Hill International, New York, NY, U.S.A.

[17] Saaty, T. L. (2008). Decision making with the analytic hierarchy process. International Journal of Services Sciences, 1(1), 83-98.

[18] Stamatakis, A., Mandalaki, M., Tsoutsos, T. (2016). Multi-criteria analysis for PV integrated in shading devices for Mediterranean region. Energy and Buildings, 117, 128-137.

[19] Šiožinytė, E., Antuchevičienè, J. (2013). Solving the problems of daylighting and tradition continuity in a reconstructed vernacular building. Journal of Civil Engineering and Management,19(6), 873-882.

[20] Triantaphyllou, E., Mann, S.H. (1995). Using the Analytic Hierarchy Process for decision making in engineering applications: some challenges. International Journal of Industrial Engineering: Applications and Practice, 2(1), 35-44.

[21] Zagorskasa, J., Zavadskasa, E.K., Turskisa, Z., Burinskien ea, M., Blumbergab, A., Blumberga, D. (2014). Thermal insulation alternatives of historic brick buildings in Baltic Sea Region. Energy and Buildings, 78, 3542.

[22] Zavadskas, E.K., Kaklauskas, A.,Turskis, Z., Tamošaitiene, J. (2008). Selection of the effective dwelling house walls by applying attributes values determined at intervals. Journal of Civil Engineering and Management,14(2), 85-93. 